\title{
Localized Suppression of Cortical Growth Hormone-Releasing Hormone Receptors State-Specifically Attenuates Electroencephalographic Delta Waves
}

\author{
Fan Liao, Ping Taishi, Lynn Churchill, Marcus J. Urza, and James M. Krueger \\ Sleep and Performance Research Center, Department of Veterinary and Comparative Anatomy, Pharmacology and Physiology, College of Veterinary \\ Medicine, Washington State University, Pullman, Washington 99164-6520
}

\begin{abstract}
Growth hormone-releasing hormone (GHRH) promotes non-rapid eye movement sleep (NREMS), in part via a well characterized hypothalamic sleep-promoting site. However, GHRH may also act in the cortex to influence sleep. Application of GHRH to the surface of the cortex changes electroencephalographic (EEG) delta power. GHRH and the GHRH receptor (GHRHR) mRNAs are detectable in the rat cortex, and the expression of cortical GHRHR is activity dependent. Here, we microinjected a GHRH antagonist or GHRHR small interfering RNA (siGHRHR) onto the somatosensory cortex surface in rats. The unilateral application of the GHRH antagonist ipsilaterally decreased EEG delta wave power during NREMS, but not wakefulness, during the initial 40 min after injection. Similarly, the injection of siGHRHR reduced cortical expression of GHRHR and suppressed NREMS EEG delta wave power during 20-24 h after injection. Using the fura-2 calcium imaging technique, cultured cortical cells responded to GHRH by increasing intracellular calcium. Approximately $18 \%$ of the GHRH-responsive cells were GABAergic as illustrated by glutamic acid decarboxylase-67 (GAD67) immunostaining. Double labeling for GAD67 and GHRHR in vitro and in vivo indicated that only a minority of cortical GHRHR-containing cells were GABAergic. Our data suggest that endogenous cortical GHRH activates local cortical cells to affect EEG delta wave power state-specifically. Results are also consistent with the hypothesis that GHRH contributes to local network state regulation.
\end{abstract}

\section{Introduction}

Growth hormone-releasing hormone (GHRH) is involved in sleep regulation (Obál, 1986; Obál et al., 1988, 2003; Steiger et al., 1992). Specifically, central or systemic administration of GHRH enhances non-rapid eye movement sleep (NREMS), whereas inhibition of endogenous GHRH suppresses spontaneous NREMS (Obál et al., 1991, 1992). The chronic disruption of GHRH mechanisms in several mutant animal models is associated with disturbed sleep. For instance, mice lacking functional GHRH receptors have less spontaneous NREMS, rapid eye movement sleep (REMS), and circulating growth hormone (GH); GH replacement rescues REMS but not NREMS (Obál et al., 2001, 2003). The hypothalamus is a site of action for GHRH-mediated NREMS. Microinjection of GHRH into the anterior hypothalamus enhances NREMS, whereas hypothalamic injection of a GHRH antagonist decreases NREMS (Zhang et al., 1999). Furthermore, hypothalamic GHRH mRNA levels and GHRH release vary with daily sleep rhythms and are enhanced during sleep deprivation (Toppila et al., 1997; Zhang et al., 1998).

\footnotetext{
Received Dec. 7, 2009; revised Jan. 19, 2010; accepted Jan. 27, 2010.

This work was supported by National Institutes of Health Grants NS27250 and NS31453. We thank Dr. Parijat Sengupta for help with confocal microscopy and Dr. Alok De for advice on $\mathrm{Ca}^{2+}$ imaging procedures.

Correspondence should be addressed to James M. Krueger, Department of Veterinary and Comparative Anatomy, Pharmacology and Physiology, College of Veterinary Medicine, Washington State University, Pullman, WA 991646520. E-mail: krueger@vetmed.wsu.edu.

DOI:10.1523/JNEUROSCI.6047-09.2010

Copyright $\odot 2010$ the authors $\quad 0270-6474 / 10 / 304151-09 \$ 15.00 / 0$
}

Hypothalamic or intraventricular injections of GHRH also enhance another sleep phenotype, electroencephalographic (EEG) slow wave activity (SWA) (0.5-4 Hz). EEG SWA is considered an index of NREMS intensity because it is enhanced during the NREMS that occurs after sleep deprivation and it is a useful quantitative parameter in the two-process model of sleep regulation (Pappenheimer et al., 1975; Borbély, 1982). EEG SWA is regulated independently from sleep duration (for review, see Kapás et al., 2008). EEG SWA also seems to reflect previous neuronal activity within local circuits (for review, see Krueger et al., 2008). Thus, targeted sensory activation of the somatosensory cortex is followed by enhanced EEG SWA during subsequent NREMS (Kattler et al., 1994; Huber et al., 2004). Conversely, targeted reduction of afferent activity during waking is followed by reduced EEG SWA in subsequent NREMS (Huber et al., 2006). Furthermore, EEG SWA is regulated, in part, via intrinsic cortical mechanisms (Steriade, 2003; Gerashchenko et al., 2008).

Cortical GHRH receptors (GHRHRs) are functional and may play a role in EEG SWA regulation. GHRH- and GHRHRimmunoreactive cells and GHRH and GHRHR mRNAs exist in the cortex (Matsubara et al., 1995; Peterfi et al., 2006; Szentirmai et al., 2007). The cortical GHRHRs are functional. Unilateral microinjection of GHRH locally onto the surface of the cortex changes subsequent EEG SWA ipsilaterally during NREMS, but not during REMS or wakefulness (Szentirmai et al., 2007). The expression of cortical GHRH is enhanced by sleep deprivation (Szentirmai et al., 2007), and neuronal GHRHR expression is associated with cortical column neuronal activity (De et al., 
2006). However, it remains unknown whether endogenous cortical GHRH contributes to these NREMS-specific EEG SWA effects, or how GHRH-receptive cells respond to GHRH or whether cortical GHRH-receptive neurons, like hypothalamic GHRH-receptive cells, have a GABAergic phenotype. We report herein that unilateral blockade of cortical GHRH statespecifically decreased ipsilateral EEG SWA. Furthermore, GHRH enhanced intracellular $\mathrm{Ca}^{2+}$ but most of these cells lacked the GABAergic phenotype. Results reinforce the concept of a GHRH contribution to local network state regulation.

\section{Materials and Methods}

\section{Animals, surgery, recordings, and statistics}

The surgical procedures were performed as described previously (Szentirmai et al., 2007). Institutional guidelines for the care and use of research animals were followed, and the experimental protocols were approved by the Institutional Animal Care and Use Committee. Using ketamine $(87 \mathrm{mg} / \mathrm{kg}$ ) and xylazine $(13 \mathrm{mg} / \mathrm{kg}$ ) for anesthesia, rats (males; Sprague Dawley; $300-330 \mathrm{~g}$; kept at $24^{\circ} \mathrm{C}$ on a $12 \mathrm{~h}$ light/dark cycle) were provided two cortical EEG electrodes over the somatosensory cortex (Sctx) (bregma coordinates: $2.5 \mathrm{~mm}$ anteroposterior, $5.5 \mathrm{~mm}$ mediolateral) on each brain hemisphere and one electromyographic (EMG) electrode in the nuchal muscles. In addition, a common reference EEG electrode was implanted $10 \mathrm{~mm}$ posterior to bregma on the midline over the cerebellum. Lead wires were fitted to a miniature plug and attached to the skull with dental cement (Duz-All; Coralite Dental Products). Two injection guide cannulae, one for each hemisphere, were implanted between the surface of the Sctx and the dura with their tips positioned under the EEG electrodes for injections. To verify the location of the microinjection cannulae, immediately after surgery while under ketamine-xylazine anesthesia, $1 \mu \mathrm{l}$ of $20 \%$ lidocaine was injected via the cannulae guide through an injection needle that pierced the dura (lidocaine induced decreases in EEG power). Only animals with correctly placed cannulae were included in the data analysis. The rats were placed in their home cages inside environmental chambers (Hotpack 352600) and given $10 \mathrm{~d}$ to recover from the surgery.

A flexible tether (Plastics One) connected the EEG and EMG electrodes to an electronic swivel as described previously (Taishi et al., 2007). After the $10 \mathrm{~d}$ recovery from surgery, rats were given $3 \mathrm{~d}$ to acclimate to this experimental condition. During each of the acclimation days, the rats were handled for $10 \mathrm{~min}$ during the $40 \mathrm{~min}$ period just before dark onset. Recordings began at dark onset (7:00 P.M.). The vigilance states NREMS, REMS, and wake were determined off-line in $10 \mathrm{~s}$ epochs using previously published criteria (Zhang et al., 1999). For power spectra analyses, only the pure-state epochs without state transitions or any artifact within them were included.

Two-way ANOVA for repeated measures was performed to analyze the sleep duration, EEG SWA, and EEG power spectra. Time blocks of 40 min (antagonist treatment) and $2 \mathrm{~h}$ [GHRHR small interfering RNA (siGHRHR) treatment] were used for sleep duration. Treatment (between baseline recording day and treatment day) and time were the two factors of the two-way ANOVA. For EEG SWA during each time block, treatment effect (between the reagent injection side and vehicle injection side) and time were the two factors of the two-way ANOVA. Then the EEG power spectra for individual time blocks were analyzed, using treatment (between the reagent injection side and vehicle injection side) and frequency as the two factors of the two-way ANOVA. When significant differences were detected by ANOVA, Fisher's least significant difference (LSD) multiple-comparison test was used to detect what time block or frequency was changed.

\section{Experiment 1: microinjection of a GHRH antagonist onto the cortex}

On the baseline recording day, $1 \mu \mathrm{l}$ of saline was injected onto each side of the brain at dark onset and the EEG was recorded. On the following day, one side of the brain received $5 \mathrm{nmol}$ of the GHRH antagonist $\left[\right.$ Phenylac-Tyr ${ }^{1}, \mathrm{D}-\mathrm{Arg}^{2},{ }^{2}$-chloro-Phe ${ }^{6}, \mathrm{Arg}^{9}, \mathrm{Abu}^{15}, \mathrm{Nle}^{27}, \mathrm{D}-\mathrm{Arg}^{28}$,
Homoarg ${ }^{29}$-GRF (1-29); Bachem], whereas the opposite control side received the same volume of saline $(n=9)$. For the injections, each rat was disconnected from its tether and removed from its environmental chamber for $\sim 5 \mathrm{~min}$. Each injection took $\sim 2 \mathrm{~min}$. Experiments were performed using four rats in each series to minimize the time between treatment and dark onset (6:20 P.M. and 7:00 P.M.). After the injection, EEG and EMG were continuously recorded for $1 \mathrm{~d}$. EEG SWA $(0.5-4 \mathrm{~Hz})$ during various states was normalized by dividing by the baseline values of the same side of brain at the same time periods after saline injection to minimize the impact of the injections (Taishi et al., 2007). Only the data from the first $2 \mathrm{~h}$ post-antagonist injection period were analyzed because it was previously reported that the antagonist has a limited duration effect (Varga et al., 1999). Only the first two $40 \mathrm{~min}$ periods were used for statistical analyses. During the first $40 \mathrm{~min}$ after GHRH antagonist injection, only five of the nine rats had REMS.

\section{Experiment 2: microinjection of siGHRHR onto the cortex}

For the siGHRHR injection $(n=7)$, the baseline EEG was recorded for $1 \mathrm{~d}$ before the injection. On the experimental day, $0.1 \mathrm{nmol}$ of GHRHR siRNA (sense, 5'-CGCUGUUUGGAAUUCAUUAtt-3'; antisense, 5'UAAUGAAUUCCAAACAGCGgg-3'; s129475; Ambion) was injected on one side of the Sctx, whereas the opposite side received $0.1 \mathrm{nmol}$ of scrambled siRNA (Ambion) as a negative control. After the injection, EEG and EMG were recorded for $2 \mathrm{~d}$ because previous studies indicated that another siRNA begins to have sleep effects $\sim 24 \mathrm{~h}$ after injection (Taishi et al., 2007). Because we did not know exactly when and how long the GHRHR siRNA would act, there were no injections on the baseline day. Therefore, the average power of EEG SWA during NREMS throughout the $23 \mathrm{~h}$ baseline-recording period was normalized to $100 \%$ for each animal.

\section{Experiment 3: GHRHR gene knockdown induced by siGHRHR}

Experiment 3a: RNA analyses of siGHRHR-treated cortical tissue At least $10 \mathrm{~d}$ after completion of the EEG recordings described above, the same rats $(n=7)$ in experiment 2 were again microinjected at dark onset with the same doses of siGHRHR or scrambled siRNA as previously used in the EEG studies. Rats were killed $20 \mathrm{~h}$ after the injection and the area around the tip of the microinjection cannulae was quickly dissected and immediately placed in RNAlater (Ambion) and stored at $-20^{\circ} \mathrm{C}$ until preparation for real-time PCR analyses.

The RNA extraction, cDNA preparation, PCR amplification, and gel electrophoresis were performed as previously described (Bredow et al., 1996). Total RNA was extracted by the acid guanidinium-phenol-chloroform method using TRIzol reagent according to the manufacturer's instructions (Invitrogen). At the end of the isolation procedure, the RNA pellets were suspended in DNase I buffer that contained $1 \mathrm{U}$ of SUPERase.In and $2 \mathrm{U}$ of DNA-free (Ambion) and were then incubated at $37^{\circ} \mathrm{C}$ for $90 \mathrm{~min}$ to degrade contaminating DNA. The RNA concentration was estimated by UV absorbance at $260 / 280$, and the quality of the RNA was verified by $1 \%$ agarose gel electrophoresis.

cDNA was synthesized using Superscript III (Invitrogen). Two micrograms of total RNA were heated together with $0.5 \mu$ g oligo-dT $_{12-18}$ and 1 $\mu \mathrm{l}$ of $10 \mathrm{~mm}$ dNTPs at $65^{\circ} \mathrm{C}$ for $5 \mathrm{~min}$, and then chilled on ice. DTT $(0.1 \mathrm{M})$, RNaseOUT (Invitrogen), $200 \mathrm{U}$ of Superscript III, and $5 \times$ firststrand buffer were added, and the mixture was incubated at $55^{\circ} \mathrm{C}$ for 60 $\mathrm{min}$. The reaction was stopped by incubating at $70^{\circ} \mathrm{C}$ for $15 \mathrm{~min}$ and then cooled to $4^{\circ} \mathrm{C}$. The RNA template was degraded for $20 \mathrm{~min}$ at $37^{\circ} \mathrm{C}$ with RNase H. Samples were diluted with sterile DNase-free water, aliquoted, and stored at $-20^{\circ} \mathrm{C}$.

Real-time PCRs were performed as previously described (Taishi et al., 2004). Briefly, the PCR mixture ( $25 \mu \mathrm{l})$ contained $5 \mu \mathrm{l}$ of diluted cDNA (100 ng total RNA equivalents for GHRHR; $10 \mathrm{ng}$ for cyclophilin A), 12.5 $\mu \mathrm{l}$ of $2 \times$ PLATINUM Quantitative PCR SuperMix-UDG (Invitrogen), $0.25 \mu \mathrm{l}$ of 1:1000 dilutions of SYBR Green (Invitrogen) and fluorescein (Bio-Rad), and $0.5 \mu \mathrm{l}$ of $10 \mu \mathrm{m}$ primers for GHRHR (5' -CTCCATTGTAGCCCTCTGCGTG-3'; $5^{\prime}$-AGGAACACAGCACTGGCCTTGA-3') and cyclophilin A ( $5^{\prime}$-aaatgctggaccaaacacaaa- $3^{\prime} ; 5^{\prime}$-ctcatgccttctttcaccttc$\left.3^{\prime}\right)$; these primers recognize all three isoforms of the GHRHR. Reactions 
were performed in triplicate, and threshold cycle $(\mathrm{Ct})$ values were averaged. Gene expression was analyzed by the comparative Ct method using the following formula: $2^{-\Delta \Delta \mathrm{Ct}}$ (Szentirmai et al., 2007). The fold changes between the mRNA expression levels of the siGHRHR- and the scrambled siRNA-treated samples were calculated. Results are expressed as relative change compared with cyclophilin. Paired $t$ tests were performed to compare GHRHR mRNA values obtained from the scrambled siRNA- and siGHRHR-treated sides of the same rat brains. The dissociation curves of used primer pairs showed a single peak, and PCR products had a single expected DNA band when run on an agarose gel (data not shown).

\section{Experiment 3b: GHRHR-immunoreactive cells of}

\section{siGHRHR-treated cortical tissue}

Rats $(n=8)$ were implanted with EEG and guide cannulae as in experiment 2. At dark onset, rats were injected with the same doses of siGHRHR on one hemisphere and scrambled siRNA on the other hemisphere as described in experiment 2. Twenty-two hours after the injection, the rats were anesthetized using isoflurane and then perfused with warm saline followed by $4 \%$ paraformaldehyde. Brains were removed and processed for GHRHR immunohistochemistry.

For GHRHR immunohistochemistry, nonspecific binding sites were blocked with $3 \%$ normal goat serum for $1 \mathrm{~h}$ at room temperature. The brain slices were incubated with 1:5000 polyclonal rabbit anti-GHRHR (Bio-Synthesis) made against a peptide sequence on the third extracellular loop: $\mathrm{NH}_{2}$-GCDSAGLGIRLPLE-OH for $3 \mathrm{~d}$ at $4^{\circ} \mathrm{C}$ followed by a $2 \mathrm{~h}$ incubation of 1:500 secondary biotinylated goat anti-rabbit IgG (Vector Laboratories). Then the brain slices were incubated with ABC complex (Vector Laboratories) for $90 \mathrm{~min}$ and then developed with diaminobenzidine (DAB) $/ \mathrm{NiCl}_{2}$ (Vector Laboratories). Photomicrographs of Sctx sections $0.5 \mathrm{~mm}$ lateral to the injection sites were prepared using a $40 \times$ objective on a Leica DMLB microscope with a Spot digital camera. The number of GHRHR-immunoreactive layer $\mathrm{V}$ pyramidal neurons within each figure $(660 \times 540 \mu \mathrm{m})$ was counted and normalized by dividing with the average number of cells in the same area on the control side of the same animal. The numbers of GHRHR-immunoreactive pyramidal cells in siGHRHR- and scrambled siRNA-injected sides of the same rat brains were compared statistically using a paired $t$ test $(n=8)$.

The specificity of the GHRHR antibody was previously described (Peterfi et al., 2006). Western blots showed the detection of a $47 \mathrm{kDa}$ band. There was no signal when the primary antibody was absent or preincubated with a GHRHR peptide.

\section{Experiment 3c: Western blots for GHRHR protein after siGHRHR treatment}

Rats were implanted with EEG and guide cannulae using the surgical procedures as in experiment 2 . At dark onset, rats $(n=8)$ were injected with the same doses of siGHRHR on one side and scrambled siRNA on the other side as in experiment 2 . Between 20 and $22 \mathrm{~h}$ after injection, rats were killed and the area around the tip of the microinjection cannulae was quickly dissected and immediately frozen in liquid nitrogen. All samples were stored at $-70^{\circ} \mathrm{C}$ until Western blot analyses. Western blots of GHRHR were performed as previously described (Szentirmai et al., 2007). The levels of GHRHR were normalized using GAPDH values from the same sample. A paired $t$ test was used to compare the siGHRHR- and scrambled siRNA-injected sides of the same rats.

\section{Experiment 4: in vitro GHRH-induced changes in free intracellular $\mathrm{Ca}^{2+}$ and cell phenotype identification}

\section{Experiment 4a: detection of GHRHR-responsive cortical cells}

Primary cortical cells were dissected from Sprague Dawley rat embryonic day 18 fetuses and cultured on glass coverslips for 10-12 d. One culture was performed each week using one pregnant rat. Cells from 31 coverslips from eight cultures were challenged with $100 \mathrm{~nm} \mathrm{GHRH}$, and the cytosolic $\mathrm{Ca}^{2+}$ levels were monitored by $\mathrm{Ca}^{2+}$ imaging.

Primary cortical cell cultures. Primary cultures of fetal cerebral cortex cells were prepared as previously described (Simasko et al., 1999) with slight modifications. Briefly, cortices were placed in ice-cold HBSS containing 1\% Fungi-bact, $0.1 \%$ BSA, and $200 \mathrm{~mm}$ ascorbic acid. The cortices were washed three times in HBSS, and the tissue was incubated at $37^{\circ} \mathrm{C}$ for $15 \mathrm{~min}$. Then the cortices were resuspended in DMEM and mechanically dissociated by gently passing three times through a 20 gauge needle fixed to a $20 \mathrm{ml}$ syringe followed by a 22 gauge needle. After centrifugation at $1200 \mathrm{rpm}$ for $5 \mathrm{~min}$, cells were resuspended in DMEM containing $10 \%$ fetal bovine serum and filtered through a $70-\mu \mathrm{m}$-pore cell strainer. Cells were then plated at a density of $2 \times 10^{6}$ cells/coverslip. The coverslips had previously been coated with $100 \mu \mathrm{g} / \mathrm{ml}$ polyornithine in $0.15 \mathrm{~m}$ borate buffer, $\mathrm{pH}$ 8.4. After $2 \mathrm{~d}$, the medium was replaced with a serum-free medium containing DMEM supplemented with $30 \mathrm{nM} \mathrm{se}-$ lenium, $20 \mathrm{~nm}$ progesterone, $1 \mu \mathrm{M}$ iron-free human transferrin, $100 \mu \mathrm{M}$ putrescine, and $5 \mu \mathrm{g} / \mathrm{ml}$ insulin. Medium was then replaced every $2 \mathrm{~d}$ until the cells were used for experiments. All buffer components were obtained from Sigma-Aldrich except fetal bovine serum (HyClone).

Calcium measurements. Cytoplasmic $\mathrm{Ca}^{2+}$ levels were measured with fura-2 using dual-wavelength fluorescent measurements with an imagingbased detection system (MetaFluor; Molecular Devices) as described previously (De et al., 2002) with slight modification. The average ratio of fluorescence intensities (340/380) for an area of the image over a cell was used to estimate cytoplasmic $\mathrm{Ca}^{2+}$ levels. For data analyses, only cells in which the basal level of $\mathrm{Ca}^{2+}$ was between 0 and $200 \mathrm{~nm}$ were included. It was reasoned that cells with $>200 \mathrm{~nm}$ basal $\mathrm{Ca}^{2+}$ may represent cells that were dying or stressed. A positive response to a GHRH challenge was defined as a change of $>20 \mathrm{~nm}$ or $5 \%$ of the basal value, whichever was greater. For GHRH challenge, the number of cells from all the coverslips was summarized, and the ratio of GHRH-responsive cells to all monitored cells was calculated.

\section{Experiment 4b: the source of increased intracellular $\mathrm{Ca}^{2+}$}

To find out the source of GHRH-induced $\mathrm{Ca}^{2+}$ spike, primary cortical cells were cultured and $\mathrm{Ca}^{2+}$ imaging was performed as experiment $4 \mathrm{a}$. Cells from 10 coverslips from five independent cultures were challenged with GHRH followed by GHRH in $\mathrm{Ca}^{2+}$-free buffer (containing $140 \mathrm{~mm}$ $\mathrm{NaCl}, 5 \mathrm{~mm} \mathrm{KCl}, 3 \mathrm{~mm} \mathrm{MgCl}$, $10 \mathrm{~mm}$ HEPES, and $6 \mathrm{~mm}$ glucose). One minute later, the cells were reperfused with standard buffer for $2 \mathrm{~min}$, and then exposed to GHRH again. Only the cells that responded to both the initial and third GHRH exposure were included in the data analysis. The responses to the second GHRH exposure were compared with the second GHRH exposure in experiment 4a using Student's $t$ test.

\section{Experiment 4c: glutamic acid decarboxylase-67 immunostaining for GHRH-responsive cells detected by $\mathrm{Ca}^{2+}$ imaging}

To identify the phenotype of the GHRH-responsive cells, glutamic acid decarboxylase-67 (GAD67) immunohistochemistry was performed after the $\mathrm{Ca}^{2+}$ measurement as previously described with minor alterations (De et al., 2002). Photomicrographs were taken at the end of $\mathrm{Ca}^{2+}$ imaging. Then the coverslips were processed for GAD67 staining using mouse anti-rat GAD67 (Millipore; MAB5406). The anti-GAD67 has no cross-reactivity with GAD65 as determined by Western blot (technical information was provided by the manufacturer), and it was used previously for immunohistochemistry on rat and mouse tissues (Gritti et al., 2006; Gvilia et al., 2006; Chen et al., 2009; Sakata et al., 2009). The specific labeling was detected by $\mathrm{DAB} / \mathrm{NiCl}_{2}$ (Vector Laboratories) staining. The GHRH-responsive cells were relocated by matching the GAD67 staining photomicrographs with the ones taken after $\mathrm{Ca}^{2+}$ imaging. Then their immunoreactivity to GAD67 was determined. Control experiments without primary antibody did not produce any labeled cells.

\section{Experiment 5: double labeling for GHRHR and GAD67}

\section{Experiment 5a: GHRHR/GAD67 double labeling in vivo}

Brain sections from the rats in experiment $3 b$ were used. Nonspecific binding sites were blocked with 5\% normal goat serum and 5\% normal chicken serum for $1 \mathrm{~h}$ at room temperature. Then the brain sections were incubated in 1:2000 mouse anti-rat GAD67 and 1:4000 rabbit anti-rat GHRHR over two nights at $4^{\circ} \mathrm{C}$. Specific binding was detected by incubation in Alexa Fluor 488 chicken anti-mouse IgG (1:500; Invitrogen) and Alexa Fluor 568 goat anti-rabbit IgG (1:500; Invitrogen) for $2 \mathrm{~h}$ at room temperature. For each brain section, at least two fields $(225 \times 225$ $\mu \mathrm{m})$ in the Sctx on the scrambled siRNA receiving side were scanned by the confocal laser scanning. GHRHR- and GAD67-immunoreactive cells 
within these fields were counted and the average was calculated. For each animal, at least six brain sections were scanned and the averages of all the sections were calculated. Two rats were excluded because of the poor quality of double labeling. The data are expressed as means $\pm \mathrm{SE}$ $(n=6)$.

\section{Experiment 5b: GHRHR/GAD67 double} labeling in vitro

Primary cortical cells were cultured for $12 \mathrm{~d}$ as in experiment $4 \mathrm{a}$. Cells from eight cultures were fixed with $4 \%$ paraformaldehyde for 30 min at room temperature $(n=8)$. Immunoreactions to GHRHR and GAD67 were performed as in experiment $5 \mathrm{a}$. The cell nuclei were stained with $2^{\prime}$-(4-hydroxyphenyl)-5-(4methyl-1-piperazinyl)-2,5'-bi(1 H-benzimidazole) trihydrochloride (bisBenzimide H33258) (5 $\mu \mathrm{g} / \mathrm{ml}$; Sigma-Aldrich). Photomicroscopy of cells was performed using a $40 \times$ objective on a fluorescence microscope (Leica). For each culture, photographs of three fields were taken and the number of cells labeled with bisBenzimide H33258, or that were GHRHRimmunoreactive, GAD67-immunoreactive, or GHRH/GAD67 double-labeled cells, were determined. The ratios of GHRHR-immunoreactive cells to cells labeled by bisBenzimide $\mathrm{H} 33258$ or the ratios of double-labeled cells to GHRHR-immunoreactive cells were calculated. The data are expressed as means $\pm \mathrm{SE}$.

\section{Results}

Experiment 1: effects of a GHRH antagonist on sleep and EEG delta wave power

Local injection of the GHRH antagonist did not alter whole animal sleep or wakefulness durations (data not shown). In contrast, the GHRH antagonist unilaterally decreased EEG delta wave power during NREMS (two-way ANOVA repeated measures; $n=9 ; p<0.05$ ), but not during wakefulness or REMS (there were few REMS epochs) during the initial $40 \mathrm{~min}$ after injection (Fig. 1A). EEG power spectra analyses showed that GHRH antagonist selectively inhibited 1-1.5 Hz slow waves (two-way ANOVA repeated measures; $n=9 ; p<0.05$ ) during NREMS, whereas the REMS and wakefulness power spectra were not affected (Fig. $1 B$ ). During the 40-80 min period after injection, the ipsilateral EEG delta power $(0.5-4 \mathrm{~Hz})$ was lower than that occurring on the control side, but this effect was not significant (Fig. 1A). During 80-120 min after injection, there were no differences in EEG slow wave power between the two sides of the cortex during NREMS, REMS, or wakefulness (data not shown).

\section{Experiment 2: effects of siGHRHR on sleep and EEG delta wave power}

The localized microinjection of the siGHRHR into the Sctx did not alter whole animal NREMS or REMS durations (data not shown). In contrast, the unilateral injection of siGHRHR reduced ipsilateral EEG delta wave power during NREMS (Fig. $2 \mathrm{~A}$ ). After the injections during the dark period of day 1 (first $12 \mathrm{~h}$ after injection) the rats exhibited their normal EEG SWA during NREMS, and there were no significant differences between the two sides of the brain. During the light period of day 1 (13-24 h after injection), there was a significant decrease in EEG SWA
B

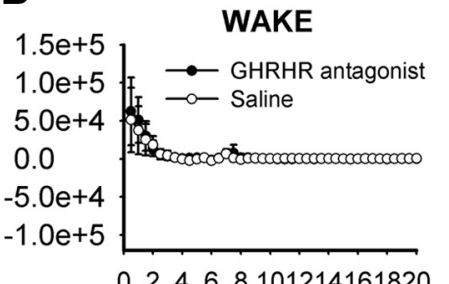

02468101214161820

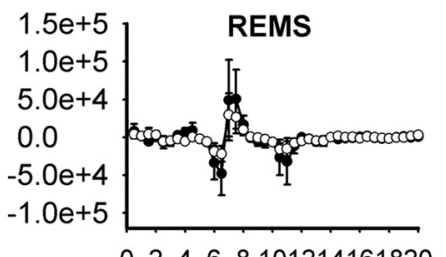

80
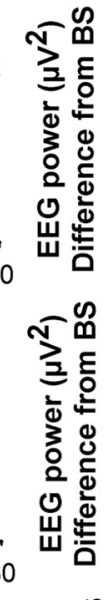

NREMS

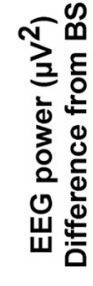

40

80

injection (min)

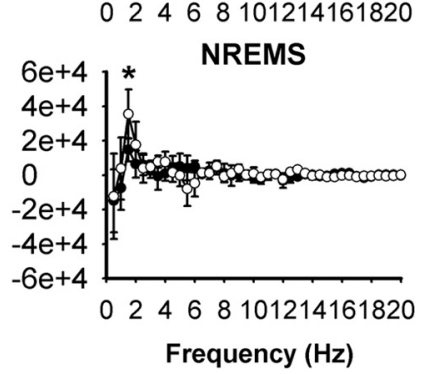

Figure 1. Effects of unilateral injection of GHRH antagonist on sleep. After baseline recordings on day 1, rats received $5 \mathrm{nmol}$ of GHRH antagonist on one side of the Sctx and saline on the contralateral Sctx at dark onset. $\boldsymbol{A}$, EEG delta wave power $(0.5-4 \mathrm{~Hz})$ during wakefulness, REMS, and NREMS after unilateral application of GHRH antagonist at dark onset. The EEG delta wave power dark onset injections of GHRH antagonist. The asterisk $\left(^{*}\right)$ indicates significant differences between two sides $(n=9 ; p<0.05$ two-way ANOVA repeated measures followed by Fisher's LSD multiple-comparison test). Error bars indicate SEM.

during NREMS on the side that received the siGHRHR compared with the side that received scrambled siRNA treatment (two-way ANOVA repeated measures; $n=7 ; p<0.05$ ). Fisher's LSD multiple-comparison tests illustrated that the differences in EEG SWA between the two sides were significant 20-24 h after injection. On postinjection day 2, siGHRHR failed to induce significant differences in EEG SWA between the two sides of the brain (Fig. 2A). There were no differences in EEG SWA during wakefulness or REMS at any time after siGHRHR treatment (Fig. 2A). Finally, EEG power spectra illustrated that, whereas slow wave power in $0.5-2.5 \mathrm{~Hz}$ was significantly reduced by siGHRHR at 20-22 h after injection (two-way ANOVA repeated measures; $n=7 ; p<0.01)$, EEG power in higher frequencies $(>4 \mathrm{~Hz})$ was not altered by the siGHRHR (Fig. $2 B$ ).

\section{Experiment 3: GHRHR gene knockdown induced by SiGHRHR}

The siGHRHR induced a $65.9 \%$ decrease (paired $t$ test; $n=7 ; p<$ 0.001) in GHRHR mRNA in the ipsilateral Sctx compared with that observed after administration of the scrambled siRNA to the contralateral Sctx at $20 \mathrm{~h}$ after injection. Western blots illustrated that, after treatment with siGHRHR for $20 \mathrm{~h}$, the GHRHR bands $(47 \mathrm{kDa})$ were less dense in comparison with the control bands (Fig. 3A). Quantitative evaluation of these GHRHR bands indicated a significant $16 \%$ decrease compared with the scrambled siRNA-treated side (paired $t$ test; $n=8 ; p<0.05$ ). siGHRHR treatment of the Sctx reduced the number of darkly stained 
A
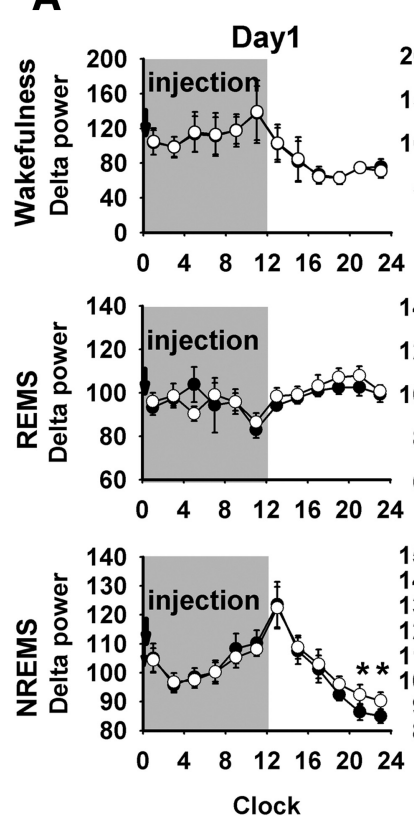

Clock
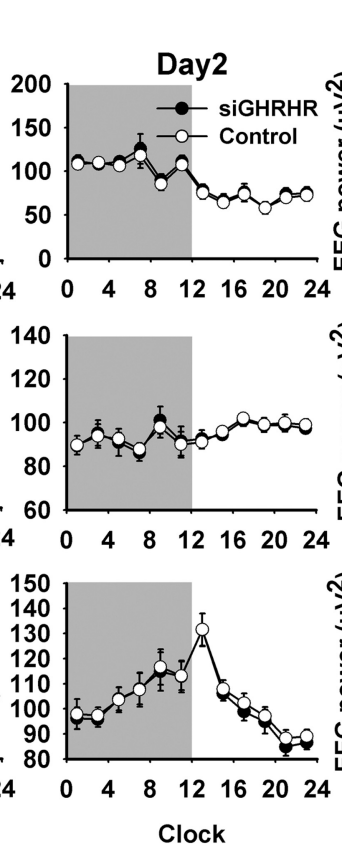

B

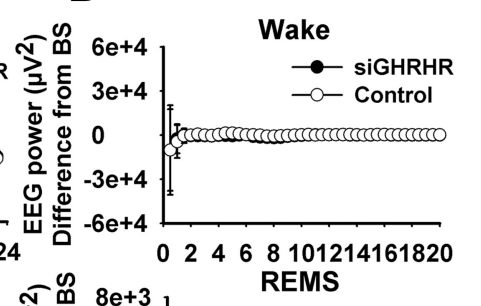

14161820
REMS

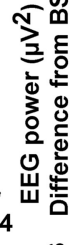

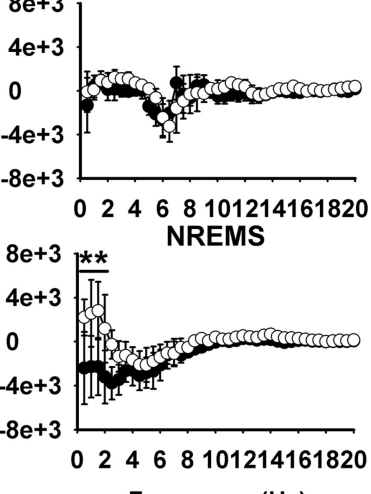

Frequency $(\mathrm{Hz})$

Figure 2. Effects of unilateral injection of siGHRHR on sleep. Rats received $0.1 \mathrm{nmol}$ of siGHRHR on one side of the Sctx and scrambled siRNA on the contralateral Sctx at dark onset. $A$, EEG delta wave $(0.5-4 \mathrm{~Hz})$ power on the siGHRHR-receiving side (O) was significantly lower than the control side $(\bigcirc)$ during $20-24 \mathrm{~h}$ after injection $\left({ }^{*} p<0.05 ; n=7\right.$; two-way ANOVA repeated measures followed by Fisher's LSD multiple-comparison test). There was no significant difference between two sides on day 2 after injection. $\boldsymbol{B}$, NREMSEEG power change from the baseline on the siGHRHR-receiving side $(O)$ and the scrambled siRNA-receiving side $(\bigcirc)$ during $20-22 \mathrm{~h}$ after dark onset injections of siGHRHR. The asterisks $\left({ }^{* *}\right)$ indicate significant differences between two sides $(n=7$; $p<0.01$; two-way ANOVA repeated measures followed by Fisher's LSD multiple-comparison test). Error bars indicate SEM.

GHRHR-immunoreactive cells in layer $\mathrm{V}$ at $22 \mathrm{~h}$ after injection. The GHRHR-immunoreactive cells illustrated in Figure 3, $B$ and $C$, were $\sim 0.5 \mathrm{~mm}$ from the siGHRHR-injected or scrambled siRNA-injected site. Quantitative evaluation of these GHRHRimmunoreactive cells indicated a significant $28.4 \%$ decrease (paired $t$ test; $n=8 ; p<0.01$ ) in cell number on the siGHRHR treatment side compared with scrambled siRNA treatment side.

Experiment 4a: detection of GHRHR-responsive cortical cells The average basal $\mathrm{Ca}^{2+}$ level for cortical neurons was $30.1 \pm 0.5$ $\mathrm{nM}(n=1531)$. GHRH $(100 \mathrm{nM})$ increased intracellular $\mathrm{Ca}^{2+}$ in $10.0 \%$ of the neurons naively exposed to GHRH ( 153 of 1531 cells tested; average response over baseline, $91.9 \pm 5.4 \mathrm{nM} ; n=153$; maximal response, $302.1 \mathrm{nM}$; results from 31 coverslips from eight cultures). When neurons were exposed to a second challenge of the GHRH 2-3 min after the first exposure, only $35.3 \%$ (54 of 153) GHRH-responsive neurons responded (Fig. 4A).

Experiment 4b: the source of increased intracellular $\mathrm{Ca}^{2+}$ The GHRH-responsive cells were further tested by using GHRH in a bath in which $\mathrm{Ca}^{2+}$ had been replaced with $\mathrm{Mg}^{2+}$ (results from 14 cells, 10 coverslips from five cultures) $\sim 2-3$ min after an exposure to GHRH. The cells responded to the initial GHRH exposure with an increase of $68.6 \pm 12.4 \mathrm{nM}(n=14)$ of $\mathrm{Ca}^{2+}$. When exposed to GHRH in $\mathrm{Ca}^{2+}$-free buffer, the $\mathrm{Ca}^{2+}$ spikes were $-2.0 \pm 1.2 \mathrm{nM}(n=14)$, which was significantly lower than the second GHRH exposure $(35.9 \pm 4.2 \mathrm{nM} ; n=153)$ in experiment $4 \mathrm{a}$ ( $p<0.001$, Student's $t$ test). When the cells were again perfused with standard buffer, the $\mathrm{Ca}^{2+}$ increase $(65.6 \pm 13.0$ $\mathrm{nM} ; n=14)$ in response to GHRH was restored. These data suggest that the GHRH-induced $\mathrm{Ca}^{2+}$ response was dependent on extracellular $\mathrm{Ca}^{2+}$.
Experiment 4c: phenotype of cortical GHRH-responsive cells

To study the phenotype of the cortical GHRH-responsive cells, we examined immunoreactivity for GAD67, a GABAergic cell marker in the GHRH-responsive cells detected by $\mathrm{Ca}^{2+}$ imaging. Seven of the 38 neurons $(18.4 \%)$ that we were able to relocate were GABAergic (Fig. 5A,B).

\section{Experiment 5: double labeling for} GHRHR and GAD in vitro and in vivo To verify the results in experiment $4 \mathrm{c}$, double-labeling immunocytochemistry for GHRHR and GAD67 (Fig. 5C-F) was performed. In the cell culture, $10.8 \pm$ $3.4 \%$ (mean $\pm \mathrm{SE} ; n=8$ ) of total cells expressed GHRHR; $32.3 \pm 4.7 \%$ (mean \pm SE; $n=8$ ) of these GHRHR-containing cells are GAD-immunopositive. We further examined the GHRHR cortical cells in the adult rat Sctx in vivo. Of the GHRHR-immunoreactive cells, $19.7 \pm$ 1.55\% (mean $\pm \mathrm{SE} ; n=6$ ) (Fig. $5 G-I$ ) were also GAD67-immunopositive.

\section{Discussion}

Our primary finding is that unilateral blockade of endogenous cortical GHRH state-specifically reduces ipsilateral EEG SWA. The GHRH antagonist-induced reductions in EEG SWA during NREMS were greatest within the first $40 \mathrm{~min}$. Others also describe a rapid onset and short duration of action of GHRH peptide antagonists. Thus, after intravenous injection of the GHRH antagonist used herein, GH secretion is maximally inhibited for $\sim 30 \mathrm{~min}$ and disappears by $60 \mathrm{~min}$ (Varga et al., 1999). Intrahypothalamic injection of another GHRH antagonist delayed the latency to the first NREMS epoch from 15 to $30 \mathrm{~min}$, decreased NREMS duration maximally within the first postinjection hour, and suppressed EEG SWA 20\% during NREMS for the first $2 \mathrm{~h}$ (Zhang et al., 1999). siGHRHR-induced unilateral downregulation of GHRHR correlated with ipsilateral EEG SWA suppression during 20-24 h after injection. The timing of these siGHRH-induced effects is consistent with previous studies showing that siRNAs effects on sleep first manifest $\sim 24$ h after injection (Chen et al., 2006; Taishi et al., 2007).

The changes in GHRH-GHRHR-induced EEG SWA are state specific, occurring only during NREMS. Mechanistically, the GHRH-mediated effects likely involve extracellular $\mathrm{Ca}^{2+}$. At a cellular level, cortical pyramidal cells characteristically oscillate between a bursting (up) state and a silent (down) state during sleep (Steriade, 2003). During NREMS, the extracelluar $\mathrm{Ca}^{2+}$ fluctuates with slow oscillations with lower levels during the depolarizing phase and higher levels during the hyperpolarizing phase (Massimini and Amzica, 2001). Thus, the high extracellular $\mathrm{Ca}^{2+}$ is expected to influence GHRH exocytosis and postsynaptically $\mathrm{Ca}^{2+}$ entry into the GHRH-receptive cells. Because the hyperpolarizing down state occurs primarily during sleep, state specificity can arise. The actions of other sleep regulatory substances on EEG SWA are also state specific (for review, see Krueger et al., 2008). For instance, application of interleukin-1 onto the Sctx enhances EEG SWA only during NREMS (Yasuda 

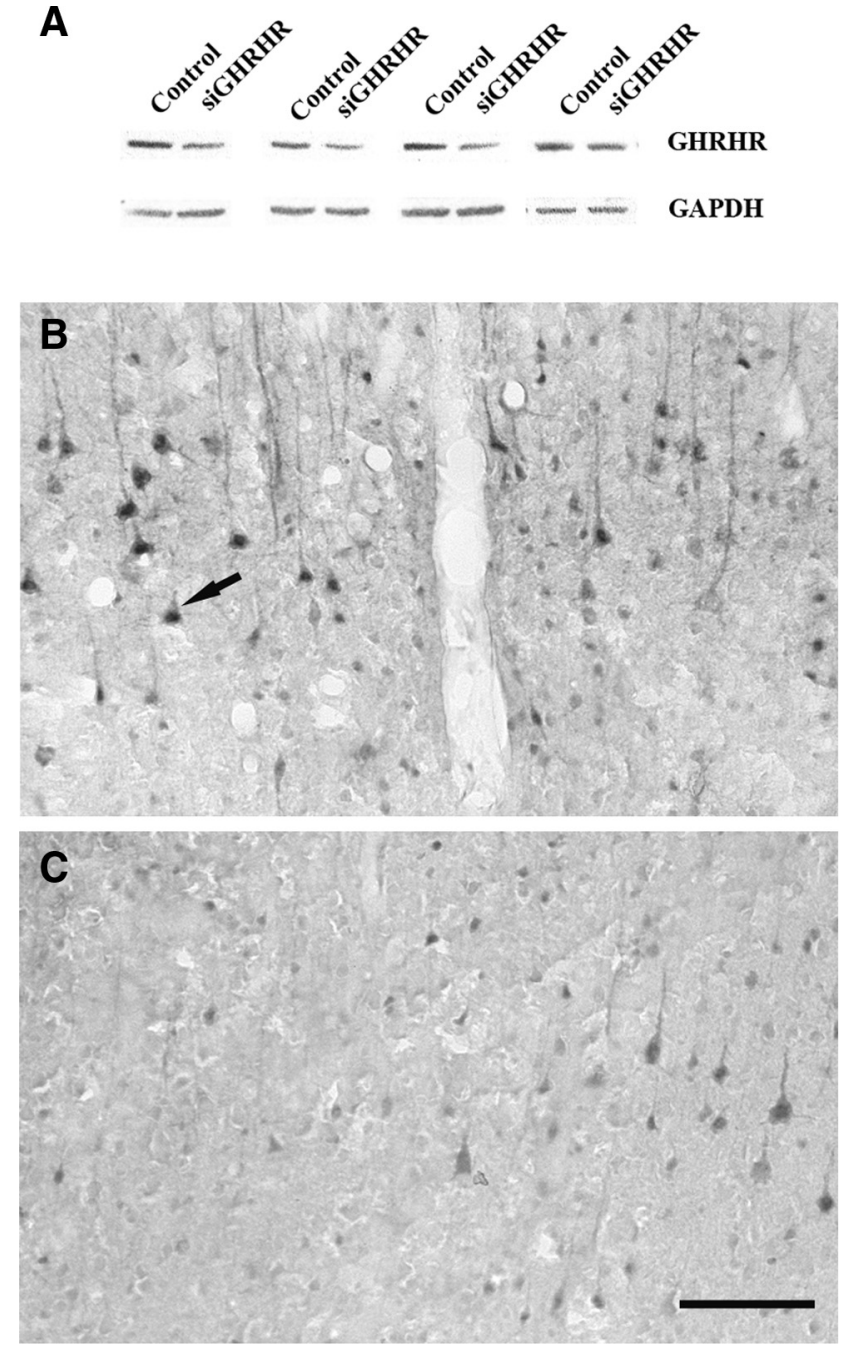

Figure 3. Effects of siGHRHR on GHRHR expression in vivo. Rats received microinjection of 0.1 nmol of siGHRHR on one side of the $S c t x$ and scrambled siRNA on the contralateral $S c t x$ at dark onset. They were killed at a time between 20 and $22 \mathrm{~h}$ after injection. $A$, Western blot of GHRHR in Sctx $20 \mathrm{~h}$ after siGHRHR or scrambled siRNA injection. $\boldsymbol{B}, \boldsymbol{C}$, Immunohistochemistry for GHRHR in Sctx $22 \mathrm{~h}$ after siGHRHR ( $\boldsymbol{C}$ ) compared with scrambled siRNA $(\boldsymbol{B})$ injection. The large pyramidal neurons in layer $V$ were dramatically reduced in GHRHR immunostaining; the arrow indicates an example of a GHRHR-immunopositive cell. Scale bar, $100 \mu \mathrm{m}$.

et al., 2005); interleukin-1 affects sleep in part via GHRH (Obál et al., 1995). Finally, that the effects of the GHRH antagonist and the siGHRHR are state specific is consistent with the hypothesis that the induced decreases in EEG SWA reflect a sleep phenotype.

The cortical origin of EEG SWA is suggested by previous studies. EEG slow oscillations $(0.5-1.5 \mathrm{~Hz})$ are generated intracortically, survive thalamectomy (Steriade et al., 1993), and are absent in the thalamus of decorticated animals (Timofeev and Steriade, 1996). Slow oscillatory field potentials occur in single cortical columns in cortical slices (Sanchez-Vives and McCormick, 2000). In addition, cortical islands, disconnected from their thalamic inputs but with blood flow maintained, exhibit local field potentials that oscillate over periods of 10-20 min between episodes of high-amplitude EEG delta waves and low EEG delta power (Kristiansen and Courtois, 1949). Those data, coupled with the current studies, suggest that GHRH plays a role in NREMS-associated slow waves of local cortical origin.

The localized EEG effects caused by the disturbance of cortical GHRH/GHRHR mechanisms observed herein are consistent
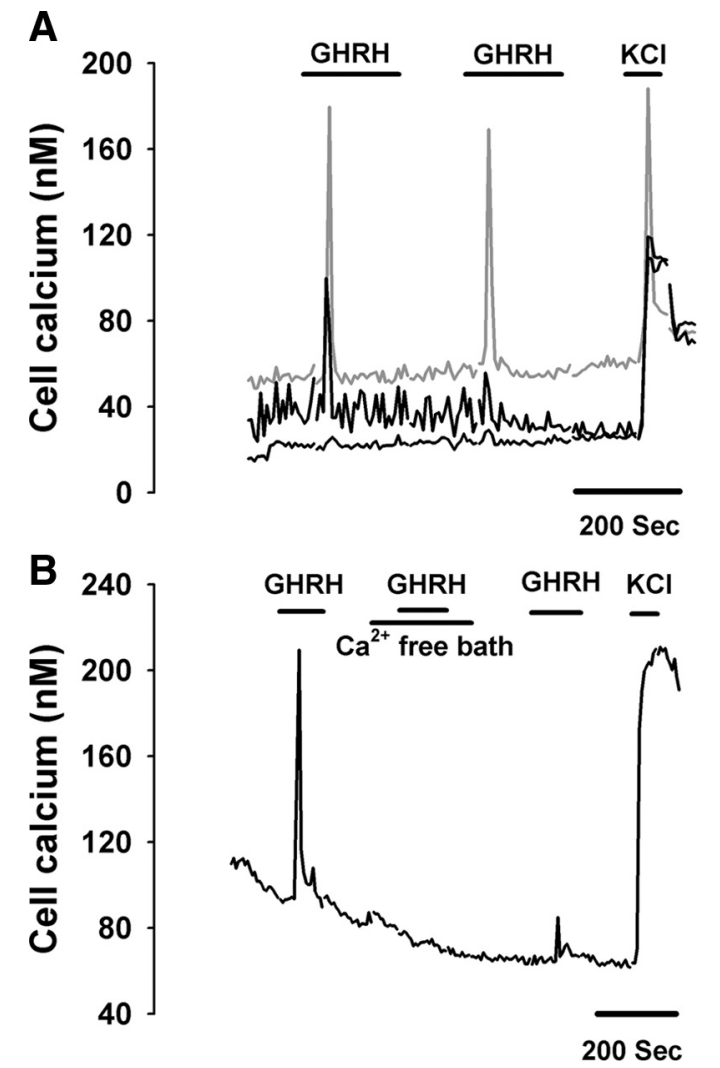

Figure 4. GHRH-evoked activation of cultured cortical neurons. Primary cortical cells were cultured and challenged with GHRH (100 nM) on culture day 10-12 in vitro. A, Representative $\mathrm{Ca}^{2+}$ response to GHRH in cultured cortical neurons. Each line on graphs illustrates the $\mathrm{Ca}^{2+}$ level in a single neuron. GHRH was applied for the duration of the labeled bars. The bar labeled $\mathrm{KCl}$ was when the neurons were depolarized with a $55 \mathrm{~mm} \mathrm{~K}^{+}$bath. $\boldsymbol{B}$, Dependence of the GHRH-induced response on extracellular $\mathrm{Ca}^{2+}$. The bar labeled with $\mathrm{Ca}^{2+}$ free indicates period when $\mathrm{Ca}^{2+}$-free bath $\left(\mathrm{Ca}^{2+}\right.$ was replaced by $\left.\mathrm{Mg}^{2+}\right)$ was applied.

with previous work. Unilateral application of GHRH to the Sctx changes ipsilateral EEG delta power during NREMS. However, high doses of GHRH enhance EEG SWA, whereas low doses decrease unilateral delta power (Szentirmai et al., 2007). The mechanisms of the bidirectional effects induced by exogenous GHRH on EEG SWA are unknown but could involve the different forms of GHRHRs expressed in the cortex (Szentirmai et al., 2007). Furthermore, a dominant-negative GHRHR splice variant that lacks the ability to stimulate cAMP has been described previously (McElvaine and Mayo, 2006). The different splice variants are differentially expressed (Szentirmai et al., 2007) and likely have different affinities for GHRH and different rates of GHRH/ GHRHR internalization. Such differences could lead to bidirectional dose-response effects. GHRH also impacts GHRHR expression. For example, in spontaneous dwarf rats, the higher cortical GHRH levels and corresponding lower numbers of GHRHRimmunopositive cells compared with controls suggests the active cortical regulation of GHRHRs (Peterfi et al., 2006). Cortical and subcortical GHRH sources may also be differentially regulated and the GHRH-responsive cortical cells could potentially integrate the effects of GHRH from these different origins. This could provide a mechanism for differential EEG slow wave changes in response to the neurochemical changes of other brain regions or for the declines in EEG SWA observed with aging or some mental disorders (for review, see Steiger, 2003). These GHRH-GHRHR interactions and the various GHRHR splice variants may offer a 
A
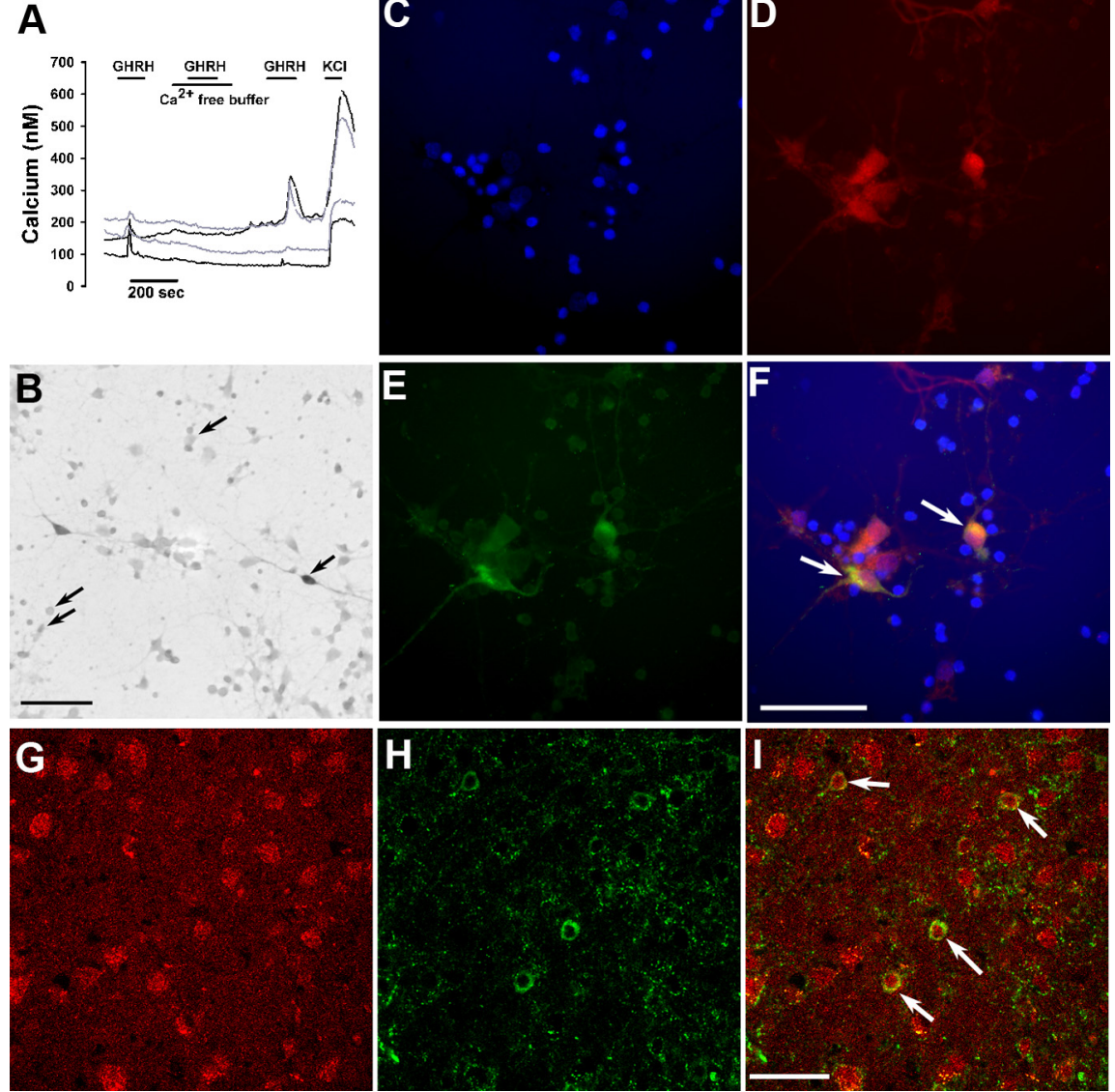

Figure 5. GAD67 immunostaining for GHRHR-containing cells. $A, B$, In primary cortical culture, GHRH-responsive cells were detected by $\mathrm{Ca}^{2+}$ imaging and then processed for GAD67 immunostaining. The arrows in $B$ show the cells present in $A$, and one of them is GAD67 positive. Scale bar, $50 \mu \mathrm{m}$. $\mathbf{C}-\boldsymbol{F}$, Immunostaining of GHRHR and GAD67 in primary cortical cultures. $\boldsymbol{C}$, Nuclear staining was demonstrated by Hoechst 33342 staining. D, GHRHR-immunoreactive cells. E, GAD67-immunoreactive cells. $\boldsymbol{F}$, All three stains were merged to demonstrate triple labeling. Two cells are double labeled (arrows) by GHRHR and GAD67. Scale bar, 50 $\mu \mathrm{m} . \mathbf{G}-\mathbf{I}$, Immunohistochemistry for GHRHR and GAD67 in Sctx. G, GHRHR-immunoreactive cells. H, GAD67-immunoreactive cells. I, Merged picture to show double labeling of GHRHR and GAD67. Four cells were double labeled by GHRHR and GAD67 (arrows). Scale bar, $50 \mu \mathrm{m}$.

partial explanation for the GHRH-EEG SWA dose-response effects. Regardless of such speculation, current data suggest that the cortical GHRH/GHRHR interaction is needed to maintain normal EEG SWA during NREMS.

Sleep seems to be a fundamental property of local neuronal networks such as cortical columns (Krueger et al., 2008). For example, cortical columns, characterized using evoked response potentials, oscillate between states (Rector et al., 2005). One of the states is sleep-like in that it has homeostatic qualities (e.g., if it is in a wake-like state for prolonged periods, it has a higher probability of transitioning into the sleep-like state). Furthermore, during whole animal sleep, most cortical columns are in a sleeplike state, but there are individual cortical columns that are in a wake-like state. Conversely, during the whole animal wakefulness, there are individual cortical columns in a sleep-like state. As monkeys enter sleep but are still performing a visual discrimination task, some neurons in the visual cortex begin to display the characteristic burst-pause sleep firing patterns. Such data also suggest that sleep develops locally (Pigarev et al., 1997). Much other data support this conclusion, ranging from the NREMS in dolphins that only occurs unilaterally (Mukhametov et al., 1977) to state separations in humans such as sleep walking (Mahowald and Schenck, 2005). Current data are consistent with the hypoth- esis that sleep, as evidenced by differential EEG SWA occurring simultaneously in both cerebral hemispheres, is initiated within local neuronal networks.

The current studies are the first to report that cortical cells respond to acute GHRH exposure with an increase of cytosolic $\mathrm{Ca}^{2+}$. GHRH enhanced cytosolic $\mathrm{Ca}^{2+}$ in $10 \%$ of the cultured cortical cells. This value is very close to the $10.8 \pm 3.4 \%$ of the cultured cells that expressed the GHRHR determined by immunocytochemistry, suggesting that those GHRHR present are functional. These GHRHreceptive cortical cells may share the same signaling pathway with somatotropes and hypothalamic neurons (De et al., 2002). GHRH elevates cytosolic $\mathrm{Ca}^{2+}$ by activating an influx of $\mathrm{Ca}^{2+}$ through voltagedependent $\mathrm{Ca}^{2+}$ channels in somatotropes (Kato et al., 1992). Similarly, we showed that GHRH-enhanced cortical intracellular $\mathrm{Ca}^{2+}$ is a result of $\mathrm{Ca}^{2+}$ influx.

The desensitization of the GHRH signaling reported here was previously observed in hypothalamic cells (De et al., 2002). Downregulation of GHRHR mRNA and internalization of GHRHR are involved in desensitization of GHRH signaling in kidney cells and somatotropes (Boisvert et al., 2002; Veyrat-Durebex et al., 2005). In our studies, the desensitization happened within minutes of the first exposure to GHRH. Inactivation of the GHRHR downstream signaling molecules that are necessary to trigger $\mathrm{Ca}^{2+}$ influx may be another desensitization mechanism. Thus, preincubation of hamster kidney cells and rat somatotropes with GHRH peptide greatly reduces GHRHinduced adenylate cyclase activity, cAMP production, and GH release (Hansen et al., 2001). The maximum reduction of adenylate cyclase was observed within 2-5 min after GHRH preexposure. Although we do not know whether the GHRH-mediated $\mathrm{Ca}^{2+}$ increase in the cortical cells depends on the adenylate cyclase/cAMP system, our finding that a 2-3 min exposure to GHRH silenced the GHRH-induced $\mathrm{Ca}^{2+}$ spike in $>60 \%$ of the cells is another example of rapid desensitization after short exposure of GHRH. In addition, the fact that some GHRH-responsive cells are not desensitized by preexposure of GHRH implies the diversity of the GHRH-responsive cortical cells.

The role of cortical GABAergic neurons in sleep regulation is incompletely characterized, although sleep modifies GAD mRNA in cortical neurons (Churchill et al., 2001) and a subset of cortical GABAergic interneurons, identified by anatomical shape and that express neuronal nitric oxide synthase, is activated during sleep (Gerashchenko et al., 2008). Most evidence relating GABAergic neurons to GHRH sleep regulatory functions is from studies of subcortical mechanisms (for review, see Szymusiak and McGinty, 2008). In hypothalamus, $96 \%$ of the GHRH-responsive neurons are GABAergic (De et al., 2002). Intracerebroventricular injection of GHRH activates GABAergic neurons in the rat preoptic hypothalamus, an area involved in NREMS regulation 
(Peterfi et al., 2010). The number of activated GABAergic neurons correlates with the subsequent duration of NREMS evoked by GHRH. The GABAergic neurons in the reticular thalamus are posited to play a role in thalamocortical synchronizations (Steriade, 2001). Although it remains unknown whether cortical GHRH influences those thalamic GABAergic neurons, current work clearly implicates a cortical GHRH mechanism in EEG synchronization. However, in the cortex, the fraction of GHRHRcontaining cells that are GABAergic is similar to that in total neurons (Beaulieu, 1993).

In summary, our results suggest that GHRH activates cortical cells and endogenous cortical GHRH plays a role in localized EEG delta power. Our data clearly illustrate that at least some sleep phenotypes such as EEG SWA are local phenomena. Consequently, our results are important to hypotheses concerning the brain organization of sleep and what exactly it is that sleeps.

\section{References}

Beaulieu C (1993) Numerical data on neocortical neurons in adult rat, with special reference to the GABA population. Brain Res 609:284-292.

Boisvert C, Paré C, Veyrat-Durebex C, Robert A, Dubuisson S, Morel G, Gaudreau P (2002) Localization and regulation of a functional GHRH receptor in the rat renal medulla. Endocrinology 143:1475-1484.

Borbély AA (1982) A two process model of sleep regulation. Hum Neurobiol 1:195-204.

Bredow S, Taishi P, Obál F Jr, Guha-Thakurta N, Krueger JM (1996) Hypothalamic growth hormone-releasing hormone mRNA varies across the day in rats. Neuroreport 7:2501-2505.

Chen CY, Bechtold AG, Tabor J, Bonham AC (2009) Exercise reduces GABA synaptic input onto nucleus tractus solitarii baroreceptor secondorder neurons via NK1 receptor internalization in spontaneously hypertensive rats. J Neurosci 29:2754-2761.

Chen L, Thakkar MM, Winston S, Bolortuya Y, Basheer R, McCarley RW (2006) REM sleep changes in rats induced by siRNA-mediated orexin knockdown. Eur J Neurosci 24:2039-2048.

Churchill L, Taishi P, Guan Z, Chen L, Fang J, Krueger JM (2001) Sleep modifies glutamate decarboxylase mRNA within the barrel cortex of rats after a mystacial whisker trim. Sleep 24:261-266.

De A, Churchill L, Obál F Jr, Simasko SM, Krueger JM (2002) GHRH and IL1beta increase cytoplasmic $\mathrm{Ca}^{2+}$ levels in cultured hypothalamic GABAergic neurons. Brain Res 949:209-212.

De A, Fix C, Hall S, Churchill L, Krueger JM (2006) Growth hormone releasing hormone receptor-immunoreactive cells increase in the barrel field in response to whisker deflection in rats. Sleep 29:A9.

Gerashchenko D, Wisor JP, Burns D, Reh RK, Shiromani PJ, Sakurai T, de la Iglesia HO, Kilduff TS (2008) Identification of a population of sleepactive cerebral cortex neurons. Proc Natl Acad Sci U S A 105:1022710232.

Gritti I, Henny P, Galloni F, Mainville L, Mariotti M, Jones BE (2006) Stereological estimates of the basal forebrain cell population in the rat, including neurons containing choline acetyltransferase, glutamic acid decarboxylase or phosphate-activated glutaminase and colocalizing vesicular glutamate transporters. Neuroscience 143:1051-1064.

Gvilia I, Turner A, McGinty D, Szymusiak R (2006) Preoptic area neurons and the homeostatic regulation of rapid eye movement sleep. J Neurosci 26:3037-3044.

Hansen BS, Gerlach LO, Hansen A, Foged C, Andersen PH (2001) The growth hormone-releasing hormone receptor: desensitisation following short-term agonist exposure. Pharmacol Toxicol 88:81-88.

Huber R, Ghilardi MF, Massimini M, Tononi G (2004) Local sleep and learning. Nature 430:78-81.

Huber R, Ghilardi MF, Massimini M, Ferrarelli F, Riedner BA, Peterson MJ, Tononi G (2006) Arm immobilization causes cortical plastic changes and locally decreases sleep slow wave activity. Nat Neurosci 9:1169-1176.

Kapás L, Bohnet SG, Traynor TR, Majde JA, Szentirmai E, Magrath P, Taishi P, Krueger JM (2008) Spontaneous and influenza virus-induced sleep are altered in TNF-alpha double-receptor deficient mice. J Appl Physiol 105:1187-1198.

Kato M, Hoyland J, Sikdar SK, Mason WT (1992) Imaging of intracellular calcium in rat anterior pituitary cells in response to growth hormone releasing factor. J Physiol 447:171-189.

Kattler H, Dijk DJ, Borbély AA (1994) Effect of unilateral somatosensory stimulation prior to sleep on the sleep EEG in humans. J Sleep Res 3:159-164.

Kristiansen K, Courtois G (1949) Rhythmic electrical activity from isolated cerebral cortex. Electroencephalogr Clin Neurophysiol 1:265-272.

Krueger JM, Rector DM, Roy S, Van Dongen HP, Belenky G, Panksepp J (2008) Sleep as a fundamental property of neuronal assemblies. Nat Rev Neurosci 9:910-919.

Mahowald MW, Schenck CH (2005) Insights from studying human sleep disorders. Nature 437:1279-1285.

Massimini M, Amzica F (2001) Extracellular calcium fluctuations and intracellular potentials in the cortex during the slow sleep oscillation. J Neurophysiol 85:1346-1350.

Matsubara S, Sato M, Mizobuchi M, Niimi M, Takahara J (1995) Differential gene expression of growth hormone (GH)-releasing hormone (GRH) and GRH receptor in various rat tissues. Endocrinology 136:4147-4150.

McElvaine AT, Mayo KE (2006) A dominant-negative human growth hormone-releasing hormone (GHRH) receptor splice variant inhibits GHRH binding. Endocrinology 147:1884-1894.

Mukhametov LM, Supin AY, Polyakova IG (1977) Interhemispheric asymmetry of the electroencephalographic sleep patterns in dolphins. Brain Res 134:581-584.

Obál F Jr (1986) Effects of peptides (DSIP, DSIP analogues, VIP, GRF and CCK) on sleep in the rat. Clin Neuropharmacol 9:459-461.

Obál F Jr, Alföldi P, Cady AB, Johannsen L, Sary G, Krueger JM (1988) Growth hormone-releasing factor enhances sleep in rats and rabbits. Am J Physiol 255:R310-R316.

Obál F Jr, Payne L, Kapás L, Opp M, Krueger JM (1991) Inhibition of growth hormone-releasing factor suppresses both sleep and growth hormone secretion in the rat. Brain Res 557:149-153.

Obál F Jr, Payne L, Opp M, Alföldi P, Kapás L, Krueger JM (1992) Growth hormone-releasing hormone antibodies suppress sleep and prevent enhancement of sleep after sleep deprivation. Am J Physiol 263:R1078-R1085.

Obál F Jr, Fang J, Payne LC, Krueger JM (1995) Growth hormone-releasing hormone mediates the sleep-promoting activity of interleukin-1 in rats. Neuroendocrinology 61:559-565.

Obál F Jr, Fang J, Taishi P, Kacsóh B, Gardi J, Krueger JM (2001) Deficiency of growth hormone-releasing hormone signaling is associated with sleep alterations in the dwarf rat. J Neurosci 21:2912-2918.

Obál F Jr, Alt J, Taishi P, Gardi J, Krueger JM (2003) Sleep in mice with nonfunctional growth hormone-releasing hormone receptors. Am J Physiol Regul Integr Comp Physiol 284:R131-R139.

Pappenheimer JR, Koski G, Fencl V, Karnovsky ML, Krueger J (1975) Extraction of sleep-promoting factor $S$ from cerebrospinal fluid and from brains of sleep-deprived animals. J Neurophysiol 38:1299-1311.

Peterfi Z, Obál F Jr, Taishi P, Gardi J, Kacsoh B, Unterman T, Krueger JM (2006) Sleep in spontaneous dwarf rats. Brain Res 1108:133-146.

Peterfi Z, McGinty D, Sarai E, Szymusiak R (2010) Growth hormone releasing hormone (GHRH) activates sleep regulatory neurons of the rat preoptic hypothalamus. Am J Physiol Regul Integr Comp Physiol 298:R147-R156.

Pigarev IN, Nothdurft HC, Kastner S (1997) Evidence for asynchronous development of sleep in cortical areas. Neuroreport 8:2557-2560.

Rector DM, Topchiy IA, Carter KM, Rojas MJ (2005) Local functional state differences between rat cortical columns. Brain Res 1047:45-55.

Sakata K, Woo NH, Martinowich K, Greene JS, Schloesser RJ, Shen L, Lu B (2009) Critical role of promoter IV-driven BDNF transcription in GABAergic transmission and synaptic plasticity in the prefrontal cortex. Proc Natl Acad Sci U S A 106:5942-5947.

Sanchez-Vives MV, McCormick DA (2000) Cellular and network mechanisms of rhythmic recurrent activity in neocortex. Nat Neurosci 3:1027-1034.

Simasko SM, Boyadjieva N, De A, Sarkar DK (1999) Effect of ethanol on calcium regulation in rat fetal hypothalamic cells in culture. Brain Res 824:89-96.

Steiger A (2003) Sleep and endocrinology. J Intern Med 254:13-22.

Steiger A, Guldner J, Hemmeter U, Rothe B, Wiedemann K, Holsboer F (1992) Effects of growth hormone-releasing hormone and somatostatin 
on sleep EEG and nocturnal hormone secretion in male controls. Neuroendocrinology 56:566-573.

Steriade M (2001) The GABAergic reticular nucleus: a preferential target of corticothalamic projections. Proc Natl Acad Sci U S A 98:3625-3627.

Steriade M (2003) The corticothalamic system in sleep. Front Biosci 8:d878-d899.

Steriade M, Nuñez A, Amzica F (1993) Intracellular analysis of relations between the slow $(<1 \mathrm{~Hz})$ neocortical oscillation and other sleep rhythms of the electroencephalogram. J Neurosci 13:3266-3283.

Szentirmai E, Yasuda T, Taishi P, Wang M, Churchill L, Bohnet S, Magrath P, Kacsóh B, Jimenez L, Krueger JM (2007) Growth hormone-releasing hormone: cerebral cortical sleep-related EEG actions and expression. Am J Physiol Regul Integr Comp Physiol 293:R922-R930.

Szymusiak R, McGinty D (2008) Hypothalamic regulation of sleep and arousal. Ann N Y Acad Sci 1129:275-286.

Taishi P, De A, Alt J, Gardi J, Obál F Jr, Krueger JM (2004) Interleukin-1beta stimulates growth hormone-releasing hormone receptor mRNA expression in the rat hypothalamus in vitro and in vivo. J Neuroendocrinol 16:113-118.

Taishi P, Churchill L, Wang M, Kay D, Davis CJ, Guan X, De A, Yasuda T, Liao F, Krueger JM (2007) TNFalpha siRNA reduces brain TNF and EEG delta wave activity in rats. Brain Res 1156:125-132.
Timofeev I, Steriade M (1996) Low-frequency rhythms in the thalamus of intact-cortex and decorticated cats. J Neurophysiol 76:4152-4168.

Toppila J, Alanko L, Asikainen M, Tobler I, Stenberg D, Porkka-Heiskanen T (1997) Sleep deprivation increases somatostatin and growth hormonereleasing hormone messenger RNA in the rat hypothalamus. J Sleep Res 6:171-178.

Varga JL, Schally AV, Csernus VJ, Zarándi M, Halmos G, Groot K, Rékási Z (1999) Synthesis and biological evaluation of antagonists of growth hormone-releasing hormone with high and protracted in vivo activities. Proc Natl Acad Sci U S A 96:692-697.

Veyrat-Durebex C, Pomerleau L, Langlois D, Gaudreau P (2005) Internalization and trafficking of the human and rat growth hormone-releasing hormone receptor. J Cell Physiol 203:335-344.

Yasuda T, Yoshida H, Garcia-Garcia F, Kay D, Krueger JM (2005) Interleukin-1beta has a role in cerebral cortical state-dependent electroencephalographic slow-wave activity. Sleep 28:177-184.

Zhang J, Chen Z, Taishi P, Obál F Jr, Fang J, Krueger JM (1998) Sleep deprivation increases rat hypothalamic growth hormone-releasing hormone mRNA. Am J Physiol 275:R1755-R1761.

Zhang J, Obál F Jr, Zheng T, Fang J, Taishi P, Krueger JM (1999) Intrapreoptic microinjection of GHRH or its antagonist alters sleep in rats. J Neurosci 19:2187-2194. 